\title{
Effect of community-based soil and water conservation practices on arbuscular mycorrhizal fungi types, spore densities, root colonization, and soil nutrients in the northern highlands of Ethiopia
}

\author{
Mengistu Welemariam ${ }^{1 *}$, Fassil Kebede ${ }^{2}$, Bobe Bedadi ${ }^{1}$ and Emiru Birhane ${ }^{3,4}$
}

\begin{abstract}
Background: Soil and water conservation measures (SWC) have a great practical significance to the restoration of arbuscular mycorrhiza (AMF). The objective of this study was to quantify the effect of decades long community-based soil and water conservation practices on arbuscular mycorrhiza fungi spore density, woody plant root colonization, and soil nutrients.

Methods: The SWC measures considered were stone terraces, exclosures + stone terraces, exclosures alone, and adjacent non-conserved open communal grazing lands. Soil and root samples were collected from the rhizosphere of matured woody plant species using systematic sampling from $10 \mathrm{~m} \times 10 \mathrm{~m}$ plot based on slope positions. Spores were isolated using wet sieving and decanting method, while AMF fungal root colonization was done using the gridline intersection method.

Results: The study revealed that five major genera of AMF, including Glomus, Acaulospora, Gigaspora, Scutellospora, and Entrophospora were identified. Glomus was found to be the most abundant genera, which accounted for (52\%) of the total spore density, followed by Acaulospora (18\%). Besides, exclosures had the highest total spore density (60\%) being followed by stone terraces (23\%), whereas the lowest (17\%) spore density was recorded in the open communal grazing lands. Total root colonization among the treatments ranged from $48.6 \%$ in the open communal grazing lands to $68.7 \%$ in the exclosure with terraces. Hyphal colonization was higher than arbuscular and vesicular colonization. The total colonization was in the order of exclosure with terraces $>$ exclosure alone > terraces $>$ non-conserved communal grazing lands.

Conclusions: Rehabilitating the communal grazing lands with terraces and exclosure is an important approach for restoring AMF and regenerating the degraded lands.
\end{abstract}

Keywords: Arbuscular mycorrhiza, Ethiopia, Exclosure, Soil properties, Terrace

\section{Background}

Degradation of communal grazing land vegetation is a widespread problem throughout the Sub-Saharan Africa and its restoration is a challenge for the management of

\footnotetext{
*Correspondence: mengistuwel@gmail.com

${ }^{1}$ College of Agriculture and Environmental Sciences, Haramaya

University, P.O. Box 138, Dire Dawa, Ethiopia

Full list of author information is available at the end of the article
}

many semi-arid areas [1]. It is a major ecological problem in Tigray high lands northern, Ethiopia [2]. Steep slopes have been cultivated and grazed for many centuries without effective soil and water conservation measures [3]. This has accelerated the problem of land degradation [4].

Terraces and exclosures have been implemented to reverse the land degradation process $[5,6]$ and restore the natural vegetation [7]. Exclosures increased biomass, herbaceous cover, and vegetative regeneration 
[8]. Exclosures also improved soil nutrient status, and reduced soil erosion [6]. Terraces decreased surface erosion and improved soil conditions [4]. Soil quality was improved after installation terraces $[9,10]$.

Soil microbiota have been considered a vital factor for the functioning of ecosystems [11, 12]. Among the soil microbial communities, arbuscular mycorrhizal fungi (AMF) are key components [13].

Arbuscular mycorrhizal fungi are ubiquitous in natural ecosystems and form intimate symbiotic associations with the majority of terrestrial plant roots [14]. More than $80 \%$ of the terrestrial plant species are associated with mycorrhizal fungi [15]. AMF are fundamental for soil fertility enhancement [16]. They increase organic carbon content and stability, improve soil water relation, and increase phosphorus availability [17]. Mycorrhiza play a key role in regulating abiotic and biotic stresses in plants [18].

Degraded lands harbor low levels of AMF abundance and diversity [19]. Many studies found that disturbance of semi-arid ecosystems decreased mycorrhizal spore density and root colonization [20,21]. It was also reported that livestock and human disturbances decreased AMF spore density, root colonization, and nutrient availability [22]. However, establishment of exclosures on degraded communal grazing lands significantly improved spore density and root colonization [23]. Nutrient stocks and concentrations of soil organic matter (SOM), total nitrogen (TN), and available phosphorus (AP) were found higher in areas with high AMF [21].

Notwithstanding the massive undertakings of community-based soil and water conservation practices and the enormous benefits of AMF in soil fertility restoration; so far there has been no systematic study conducted on the effect of SWC practices on AMF in the area. Therefore, this study was conducted with the objective of quantifying the effect of decades old terraces, exclosures with and without terrace on AMF spore density, root colonization, and soil nutrients.

The research questions answered include the following: did the support of free grazing lands with terrace increase AMF spore density and root colonization? Could protection of free grazing lands through exclosure increase AMF spore density and root colonization? Could exclosures supported with terrace result in significant increase in AMF spore density and root colonization? Is there any correlation between spore density, root colonization, and soil nutrients?

\section{Methods}

\section{Description of the study area}

The study was conducted in Degua Temben district, which is located at $50 \mathrm{~km}$ west of Mekelle, regional capital of Tigray region, northern Ethiopia. Geographically, it is located at $13^{\circ} 16^{\prime} 23^{\prime \prime}$ to $13^{\circ} 47^{\prime} 44^{\prime \prime}$ Latitude and $39^{\circ} 3^{\prime} 17^{\prime \prime}$ to $39^{\circ} 24^{\prime} 48^{\prime \prime}$ Longitude (see Fig. 1). The area is characterized by rugged topography with some flat areas. The elevation and morphology are typical for the northern Ethiopian highlands [3].

The lithology of the study area comprises mesozoic sedimentary rocks and tertiary basalt. Soils of the study sites developed from calcium carbonate-rich parent material of the Agula shale formation, which consists mainly of marble and limestone [24]. According to World Reference Base [25] soil classification system, Calcaric Cambisols, Vertic Leptosols, Vertic Cambisols, and Lithic Leptosols are the dominant soil types in the study area.

The annual rainfall ranges from 290 to $900 \mathrm{~mm}_{\text {year }}{ }^{-1}$ with an average value of $615 \mathrm{~mm}_{\text {year }}{ }^{-1}$. The main rainy season starts in June, peaks in July and August, and trails off in September, with a growing period of between 90 and 120 days. All the study sites are classified with in mid-altitude according to the traditional agro-climatic classification system, which is used in Ethiopia.

The vegetation type of the area is open woodland and the most common woody vegetation species identified in exclosures and in communal grazing lands include Acacia etbaica, Carissa edulis, Dodonaea angustifolia, Stereospermum kunthianum, Rhus vulgaris, Senna singueana, and Euclea racemosa. The understory vegetation is also dominated by a diverse assemblage of grasses and herbs including Aristida, Eragrostis, Cenchrus, Hyparrhenia, and Sporobolus which are used to feed livestock via cut and carry system.

Mixed farming system (crop and livestock) is the livelihood in the study area. Major land uses in the study area were forest lands, cultivated lands, exclosures, and communal grazing lands.

As almost all the accessible land is over-cultivated or used intensively for grazing, protection, and conservation of these degraded sites through integrated soil and water conservation practices (ISWC) such as stone-faced terraces, enforcement of grazing restrictions and plantation development efforts are commonly practiced $[3,4]$. These activities increased woody plant regeneration, density, diversity, and abundance [26].

The most commonly accepted and applied soil and water conservation measures (i.e., terraces and exclosures with and without terraces) were established since 1997 by the community. Before their establishment, the selected SWC measures had similar history in terms of grazing with the non-conserved communal grazing lands.

Each of the three selected sites was categorized into four management units described as terrace, exclosure + terrace, exclosure alone, and non-conserved open communal grazing lands (Table 1). There was no significant difference between spatial heterogeneity 


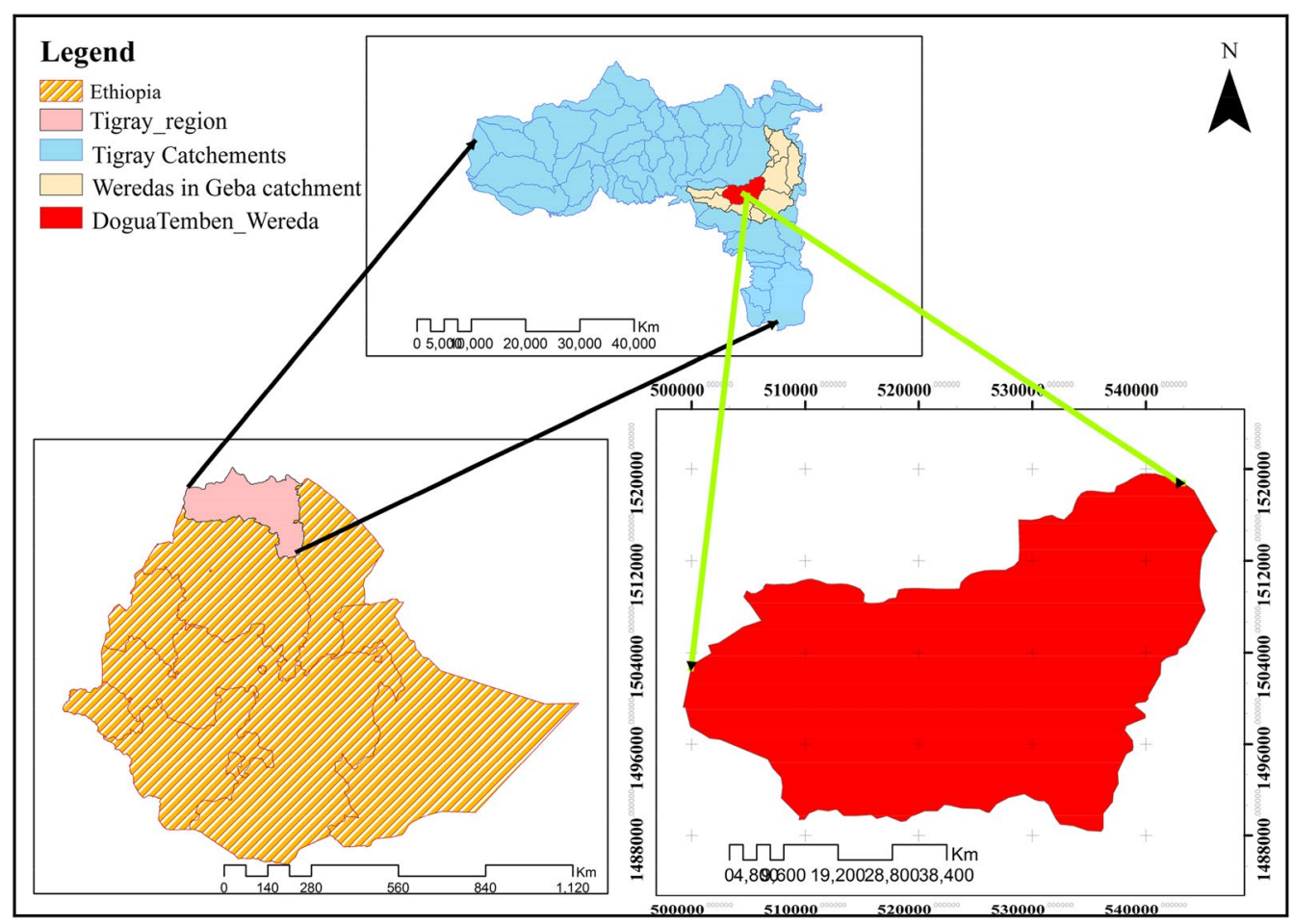

Fig. 1 Location map of the study area

(topography, soil type, vegetation, and livestock and human disturbances) among the selected sites.

\section{Experimental design}

The study was conducted in three nearby sites (Kerano, Tesemat, and Alasa within the district) and having all the SWC measures. In each SWC measure, three transects separated at a minimum distance of $75 \mathrm{~m}$ were established. The transects were parallel to each other and to the topography of the landscape. In each transect, three landscape positions (i.e., upper, middle, and foot slope) were established. The upper slope (US) position is the uppermost portion of each study site and it can receive little or no overland flow but may contribute runoff to down slope areas. The middle slope (MS) position receives overland flow from the upper slope and contributes runoff to the foot slope (FS). The FS represents the lowest part of each study site and receives overland flow from both mid and upper slopes.

Three sampling plots or quadrats of $10 \mathrm{~m} * 10 \mathrm{~m}$ size (50 $\mathrm{m}$ apart from each other) were delineated in each slope position. Soil and root samples were collected from the rhizosphere of matured woody plant species (i.e., Acacia etbaica, Carissa edulis, Dodonaea angustifolia, Stereospermum kunthianum, Rhus vulgaris, Senna singueana, and Euclea racemosa) commonly found in all soil and water conservation measures.
Isolation, enumeration, and identification of AMF spores Spores were isolated from soil samples that were collected from each corner (i.e., $0-15 \mathrm{~cm}$ from the stem) of the same and matured woody plant species in each SWC measure. Spores were isolated using $25 \mathrm{~g}$ soils by wet sieving and decanting method in a nest of three soil sieves with different mesh sizes (i.e., 300, 100, and $50 \mu \mathrm{m}$ ) and sucrose density centrifugation [27]. The residues on the sieves were washed into beaker with water and filtered through filter papers. Each filter paper was spread on petri dish and spores were counted using a dissection microscope at $40 \times$ magnification. A sporocarp was counted as one unit.

\section{Spore identification}

A compound microscope was used to identify the quantified spores to their respective genera. The identification or characterization was based on morphological characters such as spore size, color, surface ornamentation, wall structure as well as presence and absence of subtending hyphae with reference to the descriptions provided by Schüßler and Walker [28].

\section{Estimation of AMF root colonization}

The rhizosphere of each matured woody plant species was excavated up to $30 \mathrm{~cm}$ depth around all corners (i.e., $0-15 \mathrm{~cm}$ distance from the stem of the plant) at the end 
Table 1 Characteristics of the community-based soil and water conservation measures

\begin{tabular}{|c|c|}
\hline SWC measures & Characteristics \\
\hline $\begin{array}{l}\text { Non-conserved com- } \\
\text { munal grazing land }\end{array}$ & $\begin{array}{l}\text { Low vegetation cover } \\
\text { High proportion of bare soil } \\
\text { Coarse fragment ( } 57 \%) \\
\text { Sheet, rill, and gully erosion very common } \\
\text { Relatively low organic carbon (1.9\%) } \\
\text { Moisture content }(8.6 \%) \\
\text { Bulk density }\left(1290 \mathrm{~kg} \mathrm{~m}^{-3}\right) \\
\text { Area (11-34.96 ha) }\end{array}$ \\
\hline Stone terraces & $\begin{array}{l}\text { Relatively more stable and durable than other } \\
\text { physical SWC measures } \\
\text { Soil organic carbon }(2.5 \%) \\
\text { Moisture content }(9.6 \%) \\
\text { Bulk density }\left(1260 \mathrm{~kg} \mathrm{~m}^{-3}\right) \\
\text { Coarse fragment }(53 \%) \\
\text { High sediment deposit } \\
\text { Area (13.87-24.42 ha) }\end{array}$ \\
\hline Exclosure + terrace & $\begin{array}{l}\text { Closed from the interference of humans and } \\
\text { livestock } \\
\text { Enrichment planting common } \\
\text { Supported with terraces } \\
\text { High organic carbon }(2.9 \%) \\
\text { Sheet, rill, and gully formation are less common } \\
\text { Moisture content }(10.06 \%) \\
\text { Bulk density }\left(1240 \mathrm{~kg} \mathrm{~m}^{-3}\right) \\
\text { Coarse fragment }(46 \%) \\
\text { Area }(12.74-51.80 \mathrm{ha})\end{array}$ \\
\hline Exclosures alone & $\begin{array}{l}\text { Closed from humans and livestock interference } \\
\text { No enrichment planting } \\
\text { No physical SWC measures } \\
\text { High organic carbon ( } 2.8 \%) \\
\text { Moisture content }(8.7 \%) \\
\text { Bulk density }\left(1220 \mathrm{~kg} \mathrm{~m}^{-3}\right) \\
\text { Coarse fragment }(51 \%) \\
\text { Sheet, rill, and gully formation are less common } \\
\text { Area (14.02-34.7 ha) }\end{array}$ \\
\hline
\end{tabular}

of rainy season (during October). Only fine and live root samples were collected and put into plastic jar, and filled with $97 \%$ ethanol to preserve the roots until processing.

In the laboratory, the root samples were washed thoroughly in tap water, cut it to approximately $1 \mathrm{~cm}$ and cleared in $10 \% \mathrm{KOH}$ for $20 \mathrm{~min}$ at $120{ }^{\circ} \mathrm{C}$, acidified with $3 \% \mathrm{HCl}$, and stained with trypan blue. The stained root samples were mounted on microscope slides in polyvinyl lacto glycerol (PVLG) and examined for AMF colonization under light microscope. Root lengths with mycorrhizal colonization in the form of arbuscules, vesicles, and hyphae in 100 root segments from each plant species were estimated using the gridline intersection method of [29]. Finally, the average AMF root colonization of woody plant species of each plot across slope position within each SWC measure were considered to calculate and analyze AMF root colonization. Calculation was done as follows

Total intersection points $(G)$

$$
=(p+q+r+s+t+u)
$$

Total root colonization $=[(G-P) / G] * 100$

$$
\begin{aligned}
& \text { Hyphal colonization }(\mathrm{HC}) \\
& \begin{aligned}
= & {[(G-(q+r+s)-p) / G] } \\
& * 100 \text { or }(q+r+s+t) / G * 100 \\
& \text { Arbuscular colonization }(\mathrm{AC})=(q+s) / G * 100 \\
& \text { Vesicular colonization }(\mathrm{VC})=(r+s) / G * 100,
\end{aligned}
\end{aligned}
$$

where $p$ is the intersection where no fungal structures are seen, $q$ intersection is where arbuscules is seen, $r$ intersection is where mycorrhizal vesicles are seen, $s$ intersection is where arbuscules and mycorrhizal vesicles are seen, $t$ intersection is where mycorrhizal hyphae but no arbuscules or mycorrhizal vesicles are seen, $u$ intersection is where mycorrhizal hyphae is not seen is connected to arbuscules or mycorrhizal vesicles.

\section{Determination of soil physical and chemical properties}

Soil samples were collected from the top $(0-30 \mathrm{~cm})$ soil depth at a distance of 0 to $15 \mathrm{~cm}$ from the stem of the plants. In the lab, soil samples of each woody plant species were air dried and a composite soil sample was formed from each woody plant of the same species found in each SWC measure.

Soil samples were sieved through $2 \mathrm{~mm}$ mesh to remove stones, roots, and large organic residues. Soil texture was determined using a hydrometer [30], soil pH by using a combined glass electrode $\mathrm{pH}$ meters in 1:2.5 soilwater [31], soil organic (OC) by wet combustion [32], total nitrogen according to [33], and soil available $\mathrm{P}$ was determined by Olsen method [34].

\section{Data analysis}

The mean spore density, root colonization, and soil nutrients was tested using ANOVA and comparison of means was made based on Duncan's multiple range test (DMRT) using SAS 9.2. Pearson correlation coefficient was calculated to see for any correlation between the AMF spore density and root colonization and soil nutrients.

\section{Results and discussion}

Effect of community-based soil and water conservation measures on total AMF spore density

The study identified five genera of AMF that include Glomus, Acaulospora, Gigaspora, Scutellospora, and Entrophospora. Total spore density was significantly $(P<0.05)$ affected by the community-based soil and water conservation measures (Table 2). Glomus was the most abundant (52\%) genus, followed by Acaulospora (18\%). This could be due to the resistance of these genera to disturbances. Arbuscular mycorrhiza fungi species that 
Table 2 Effect of SWC measures on total spore density (mean \pm SEM)

\begin{tabular}{llccr}
\hline Spore type & Non-conserved grazing lands & Terraces & Exclosures+terraces & Exclosures alone \\
\hline Glomus & $436.7 \pm 72^{\mathrm{b}}$ & $587.8 \pm 58^{\mathrm{ab}}$ & $754.4 \pm 86^{\mathrm{a}}$ & $815.5 \pm 97^{\mathrm{a}}$ \\
Acaulospora & $142.2 \pm 22^{\mathrm{b}}$ & $230.0 \pm 42^{\mathrm{ab}}$ & $276.7 \pm 33^{\mathrm{a}}$ & $257.8 \pm 29^{\mathrm{a}}$ \\
Gigaspora & $104.4 \pm 18^{\mathrm{b}}$ & $152.2 \pm 18^{\mathrm{ab}}$ & $181.1 \pm 14^{\mathrm{a}}$ & $196.7 \pm 30^{\mathrm{a}}$ \\
Scutellospora & $125.6 \pm 18^{\mathrm{a}}$ & $142.2 \pm 21^{\mathrm{a}}$ & $193.3 \pm 27^{\mathrm{a}}$ & $188.9 \pm 18^{\mathrm{a}}$ \\
Entrophospora & $16.6 \pm 8^{\mathrm{b}}$ & $42.2 \pm 9^{\mathrm{ab}}$ & $83.3 \pm 25^{\mathrm{a}}$ & $58.9 \pm 13^{\mathrm{ab}}$ \\
Grand total & $825.6 \pm 121^{\mathrm{b}}$ & $1154.0 \pm 103^{\mathrm{ab}}$ & $1489.0 \pm 112^{\mathrm{a}}$ & $1518.0 \pm 158^{\mathrm{a}}$ \\
\hline
\end{tabular}

Means followed by the same letter across each column do not differ significantly at $P \leq 0.05$

belong to the genera Glomus and Acaulospora are resistant to soil disturbances and altered ecosystems [18, 21, 35]. They are also not host-specific and might be found to be associated with various plants in the same locality [36].

Scutellospora accounted only for 13\%, Gigaspora for 12.7\%, and Entrophospora about 4\% of the total spore density (Table 2). Glomus was the most abundant due to the fact that it is also sporageous, while Entrophospora was found to be the least abundant genus because it is sensitive to disturbances. In line with this, Glomus was abundant in Boswellia papyrifera-dominated woodlands of northern Ethiopia [8]. Likewise, Wubet et al. [37] reported that Glomus was abundant in indigenous trees in dry Afromontane forests of Ethiopia.

Basically, AMF spore densities are affected by soil erosion and mechanical disturbance due to livestock grazing. Due to this reason, the lowest spore density which accounted for $16.5 \%$ (Table 2) was found in non-conserved communal grazing lands. In connection, Muleta et al. [21] found that soil disturbance has reduced AM fungi spore densities. Particularly, AM fungi Entrophospora is sensitive to human disturbance and soil erosion. Scarcity of Entrophospora in the rhizosphere of woody plant species is attributed to the disruption of the extraradical hyphae [21].

Total spore density in the exclosures ranged from 1488.9 to 1517.8 spore $100 \mathrm{~g}^{-1}$ of dry soil while stone terraces accounted 1154 spores $100 \mathrm{~g}^{-1}$ of dry soil. Both exclosures also had significantly $(P<0.05)$ higher spore density than free grazing lands without SWC structure. This may be due to the presence of favorable environment such as high organic carbon content in exclosures. Similarly, Birhane et al. [22] found up to 2980 spores $100 \mathrm{~g}^{-1}$ dry soil in exclosures. Terraces had higher mean total spore density than free grazing land without any SWC structures (Table 2). Non-conserved open communal grazing lands had the lowest mean total AMF spore density (825 spores $100 \mathrm{~g}^{-1}$ dry soils). In this study, it is witnessed that community-based soil and water conservation (CBSWC) practices had brought significant change in spore density. Exclosures had brought about
$45.6 \%$ increment in spore density as compared to the non-conserved communal grazing lands and $28.5 \%$ against the stone terraces. Besides, a stone terrace has resulted in $24 \%$ increment in spore density as compared to the non-conserved communal grazing lands. Spore density of the different CBSWC measures was in the order of exclosures alone $>$ exclosures + terraces $>$ terraces $>$ non-conserved communal grazing lands.

\section{Effect of slope position on total AMF spore density}

The highest spore density was found at foot slope as compared to the middle and upper slope positions (Table 3). The highest spore density (i.e., 1616 spores $100 \mathrm{~g}^{-1}$ dry soil) was recorded at the foot slope in exclosures without terraces, whereas the lowest total spore density (i.e., 723 spores $100 \mathrm{~g}^{-1}$ dry soil) was found at the upper slope position in non-conserved communal grazing lands (Table 3). The variation could be due to displacement of spores by erosion from the upper to down slope position. This is in agreement to Birhane et al. [23] who found significantly higher spore density at the foot than the middle and upper slope positions. Large variations in spore density between slope positions could also be due to the properties of the soils, host relations, and the differential survival strategies of AMF [22].

\section{Effect of community-based soil and water conservation measures on AMF root colonization}

Root colonization by AMF is characterized by the presence of hyphae, arbuscules and vesicles. In this study, it was found that the different CBSWC measures had brought a significant $(P<0.05)$ variation in the total AMF root colonization. The total percent of AMF root colonization was the highest $(68.7 \%)$ in the exclosures + terrace. The lowest (48.6\%) total percent of AMF root colonization was recorded in the non-conserved communal grazing lands (Table 4). This indicated grazing decreased AMF root colonization. Grazing by herbivores decreased colonization by AMF [38]. Earlier studies reported that disturbance generally had the greatest impact on biological properties, including symbiotic fungal populations $[39,40]$. 
Table 3 Effect of slope positions on total spore density

\begin{tabular}{lllll}
\hline Slope position & Non-conserved grazing lands & Terraces & Exclosures+terraces & Exclosures alone \\
\hline Foot slope & $903.3^{\mathrm{ab}}$ & $1210.0^{\mathrm{ab}}$ & $1603.3^{\mathrm{a}}$ & $1616.6^{\mathrm{a}}$ \\
Middle slope & $850.0^{\mathrm{ab}}$ & $1066.6^{\mathrm{ab}}$ & $1466.6^{\mathrm{ab}}$ & $1506.6^{\mathrm{ab}}$ \\
Upper slope & $723.3^{\mathrm{b}}$ & $1186.6^{\mathrm{ab}}$ & $1396.6^{\mathrm{ab}}$ & $1430.0^{\mathrm{ab}}$
\end{tabular}

Means followed by the same letter do not differ significantly at $P \leq 0.05$

Table 4 Effect of SWC measures on root colonization (mean \pm SEM)

\begin{tabular}{|c|c|c|c|c|}
\hline \multirow[t]{2}{*}{ Root colonization types } & \multicolumn{4}{|l|}{ Soil and water conservation measures } \\
\hline & Non-conserved communal grazing lands & Terraces & Exclosures + terraces & Exclosures alone \\
\hline Total (\%) & $48.6 \pm 3^{c}$ & $60.5 \pm 2^{b}$ & $68.7 \pm 2^{a}$ & $67.8 \pm 4^{\mathrm{a}}$ \\
\hline Hyphal (\%) & $21.2 \pm 3^{b}$ & $28.2 \pm 4^{b}$ & $45.3 \pm 4^{\mathrm{a}}$ & $41.1 \pm 3^{\mathrm{a}}$ \\
\hline Arbuscular (\%) & $7.1 \pm 2^{b}$ & $7.6 \pm 2^{b}$ & $18.5 \pm 1^{\mathrm{a}}$ & $15.9 \pm 3^{a}$ \\
\hline Vesicular (\%) & $4.3 \pm 1^{b}$ & $8.9 \pm 3^{\mathrm{a}}$ & $12.4 \pm 1^{\mathrm{a}}$ & $12.9 \pm 2^{a}$ \\
\hline
\end{tabular}

Means followed by the same letter across each column do not differ significantly at $P \leq 0.05$

There was no significant difference in total percent of root length colonization between the two exclosure types (Table 4). However, exclosures had significantly $(P<0.05)$ higher total AMF root colonization than terraces. Besides, exclosures and terraces had significantly $(P<0.05)$ higher total AMF colonization than non-conserved communal grazing lands (Table 4). Total root colonization by AMF was in the order of exclosures + terraces $>$ exclosures alone $>$ terraces $>$ non-conserved grazing lands. The presence of high organic carbon and lower disturbance in exclosures (Table 1) could resulted in high AMF root colonization compared to terraces and non-conserved grazing lands.

Exclosures resulted about 29\% increase in total root colonization as compared to non-conserved communal grazing lands and $12 \%$ increase as compared to terraces, while terraces resulted in $20 \%$ increase in total root colonization compared to non-conserved communal grazing lands. Hyphal colonization was the highest in all conservation measures followed by arbuscular colonization but vesicular colonization was the lowest (Table 4). In many studies, it was also found that Hyphal root colonization $>$ arbuscular $>$ vesicular colonization $[8,21,22]$.

\section{Effect of community-based soil and water conservation measures on soil physicochemical properties}

Soil and water conservation had brought significant $(P<0.05)$ variation on most rhizosphere soil nutrients. Most of the rhizosphere soil nutrients were higher in exclosures and followed by terraces; and the lowest was found in non-conserved communal grazing lands (Table 5). Significant $(P<0.05)$ variation in soil organic carbon content was found between the CBSWC measures. Similarly, Demelash and Stahr et al. [41] reported that soil and water conservation measures increased the soil organic carbon content. The highest organic carbon content was found in the exclosures + terraces being followed by the exclosures alone (Table 1 ). The lowest was obtained in the non-conserved open communal grazing lands. Organic matter content of the CBSWC measures was in the order of exclosures + terraces $>$ exclosures alone $>$ terraces $>$ non-conserved grazing lands.

The $\mathrm{pH}$ content of all the soil and water conservation measures is classified as moderately alkaline [42]. This indicates the soils have calcium carbonate. $\mathrm{pH}$ was significantly $(P<0.05)$ lower in exclosures than terraced and non-terraced open communal grazing lands (Table 5). This could be due to the presence of high organic matter in exclosures. Many studies showed that ungrazed lands had high SOC but low $\mathrm{pH}$ than grazed sites $[3,25]$. The $\mathrm{pH}$ of the CBSWC measures was in the order of nonconserved communal grazing lands $>$ terraces $>$ exclosures + terraces $>$ exclosures alone.

Available phosphorus in terraced and non-terraced open communal grazing land is rated as medium, whereas it is classed as high in case of both exclosures [42]. Available potassium is rated as medium in case of terraced and non-terraced open communal grazing lands (Table 5), where as it is rated as high in case of both exclosures [43].

The total nitrogen in case of terraced and non-terraced open grazing lands is classed as high while those of both types of exclosures is rated as very high [42]. In conformity, other researchers also reported significantly higher total soil nitrogen and available potassium in exclosures than in the grazed areas [44] and on terraced than non-terraced lands [41]. 
Table 5 Effect of SWC measures on rhizosphere soil physicochemical properties

\begin{tabular}{lllll}
\hline Physicochemical properties & \multicolumn{3}{l}{ Soil and water conservation measures } \\
\cline { 2 - 4 } & Non-conserved grazing lands & Terraces & Exclosures + terraces & Exclosures alone \\
\hline pH & $8.22^{\mathrm{b}}$ & $8.21^{\mathrm{b}}$ & $8.1^{\mathrm{a}}$ & $7.9^{\mathrm{a}}$ \\
Ec (cS/M) & $0.13^{\mathrm{a}}$ & $0.12^{\mathrm{a}}$ & $0.12^{\mathrm{a}}$ & $0.11^{\mathrm{a}}$ \\
TN (\%) & $0.21^{\mathrm{c}}$ & $0.24^{\mathrm{bc}}$ & $0.28^{\mathrm{ab}}$ & $0.31^{\mathrm{a}}$ \\
Avail. P (ppm) & $4.13 \pm 1^{\mathrm{a}}$ & $4.60 \pm 1^{\mathrm{a}}$ & $5.70 \pm 1^{\mathrm{a}}$ & $6.99 \pm 1^{\mathrm{a}}$ \\
Avail. K cmol (+)/kg & $0.49^{\mathrm{b}}$ & $0.59^{\mathrm{b}}$ & $0.61^{\mathrm{b}}$ & $0.8^{\mathrm{a}}$ \\
Sand (\%) & $36.48 \pm 3^{\mathrm{a}}$ & $31.43 \pm 2^{\mathrm{b}}$ & $28.67 \pm 2^{\mathrm{b}}$ & $32.57 \pm 2^{\mathrm{ab}}$ \\
Silt (\%) & $29.81 \pm 1^{\mathrm{a}}$ & $31.33 \pm 1^{\mathrm{a}}$ & $29.81 \pm 1^{\mathrm{a}}$ & $32.38 \pm 2^{\mathrm{a}}$ \\
Clay (\%) & $33.71 \pm 3^{\mathrm{b}}$ & $37.24 \pm 1^{\mathrm{ab}}$ & $40.29 \pm 2^{\mathrm{a}}$ & $35.14 \pm 2^{\mathrm{b}}$ \\
\hline
\end{tabular}

Means followed by the same letter across each column do not differ significantly at $P \leq 0.05$

AvaP available phosphorus, AvaK available potassium, $O C$ organic carbon, $T N$ total nitrogen, Ec electrical conductivity

Table 6 Pearson correlations between rhizosphere soil properties and AMF spore densities and root colonization

\begin{tabular}{|c|c|c|c|c|c|c|c|c|c|c|c|c|c|c|}
\hline Soil properties & $\mathrm{pH}$ & EC & TN & $P$ & K & OC & Sand & Silt & Clay & Total spore & TRC & $\mathrm{HC}$ & $A C$ & VC \\
\hline $\mathrm{pH}$ & 1 & & & & & & & & & & & & & \\
\hline EC & $0.31^{* *}$ & 1 & & & & & & & & & & & & \\
\hline TN & $-0.04^{\mathrm{ns}}$ & $0.40^{* * *}$ & 1 & & & & & & & & & & & \\
\hline AvaP & $-0.05^{\mathrm{ns}}$ & $0.14^{\mathrm{ns}}$ & $0.40^{* * *}$ & 1 & & & & & & & & & & \\
\hline AvaK & $-0.34^{* *}$ & $-0.13^{\text {ns }}$ & $0.46^{* * *}$ & $0.48^{* * *}$ & 1 & & & & & & & & & \\
\hline OC & $-0.01^{\mathrm{ns}}$ & $-0.21^{*}$ & $0.16^{\mathrm{ns}}$ & $0.04^{\mathrm{ns}}$ & $0.26^{*}$ & 1 & & & & & & & & \\
\hline Sand & $-0.15^{\mathrm{ns}}$ & $0.01^{\mathrm{ns}}$ & $0.19^{\text {ns }}$ & $0.07^{\mathrm{ns}}$ & $0.05^{\mathrm{ns}}$ & $-0.07^{\mathrm{ns}}$ & 1 & & & & & & & \\
\hline Silt & $0.05^{\mathrm{ns}}$ & $-0.14^{\mathrm{ns}}$ & $-0.22^{*}$ & $0.10^{\mathrm{ns}}$ & $0.04^{\mathrm{ns}}$ & $-0.06^{\mathrm{ns}}$ & $-0.26^{*}$ & & & & & & & \\
\hline Clay & $0.10^{* *}$ & $0.05^{\mathrm{ns}}$ & $-0.05^{\mathrm{ns}}$ & $-0.12^{\mathrm{ns}}$ & $-0.07^{\mathrm{ns}}$ & $0.12^{\mathrm{ns}}$ & $-0.83^{* *}$ & $-0.31^{\mathrm{ns}}$ & 1 & & & & & \\
\hline Total spore & $0.05^{\mathrm{ns}}$ & $0.16^{\mathrm{ns}}$ & $0.46^{* * *}$ & $0.25^{*}$ & $0.33^{* * *}$ & $0.21^{*}$ & $0.21^{*}$ & $-0.11^{\mathrm{ns}}$ & $-0.15^{\mathrm{ns}}$ & 1 & & & & \\
\hline TRC & $0.26^{*}$ & $0.25^{*}$ & $0.23^{*}$ & $0.16^{\mathrm{ns}}$ & $0.05^{\mathrm{ns}}$ & $0.38^{*}$ & $-0.09^{\mathrm{ns}}$ & $0.22^{*}$ & $-0.03^{\mathrm{ns}}$ & $0.36^{*}$ & 1 & & & \\
\hline $\mathrm{HC}$ & $0.21^{\mathrm{ns}}$ & $0.25^{*}$ & $0.28^{* *}$ & $0.12^{\mathrm{ns}}$ & $0.06^{\mathrm{ns}}$ & $0.30^{* *}$ & $-0.10^{\mathrm{ns}}$ & $0.13^{\mathrm{ns}}$ & $0.03^{\mathrm{ns}}$ & $0.30^{*}$ & $0.86^{*}$ & 1 & & \\
\hline$A C$ & $0.09^{\text {ns }}$ & $0.12^{\mathrm{ns}}$ & $0.21^{*}$ & $0.17^{\mathrm{ns}}$ & $0.10^{\text {ns }}$ & $0.11^{\mathrm{ns}}$ & $-0.01^{\mathrm{ns}}$ & $0.25^{*}$ & $-0.14^{\mathrm{ns}}$ & $0.20^{*}$ & $0.51^{*}$ & $0.69^{\mathrm{ns}}$ & 1 & \\
\hline VC & $0.29^{* *}$ & $0.18^{\text {ns }}$ & $0.08^{\text {ns }}$ & $-0.03^{\mathrm{ns}}$ & $-0.01^{\mathrm{ns}}$ & $0.27^{*}$ & $-0.16^{\mathrm{ns}}$ & $0.09^{\text {ns }}$ & $0.11^{\mathrm{ns}}$ & $0.01^{\mathrm{ns}}$ & $0.67^{*}$ & $0.81^{\mathrm{ns}}$ & $0.45^{\mathrm{ns}}$ & 1 \\
\hline
\end{tabular}

* Correlation is significant at 0.05 levels (pair wise). ${ }^{* *}$ Correlation is significant at 0.01 levels (pair wise). ${ }^{* * *}$ Correlation is significant at $0.001 \mathrm{~ns}$. Correlation is not significant at $P<0.05$

\section{Relationship between AMF spore density, root colonization, and soil nutrients}

Correlation of arbuscular mycorrhizal fungal spore density and percent of total root colonization were positive and significant $(P<0.05)$. Spore density and total root colonization (TRC) were significantly $(P<0.05)$ and positively related. Total root colonization was significantly correlated with $\mathrm{pH}$ total nitrogen, organic carbon, and electrical conductivity, while total spore density was significantly correlated with total nitrogen, available phosphorus, available potassium and organic carbon (Table 6). Unlike silt and clay fraction, a positive correlation between spore density and total root colonization (TRC), and sand fraction was observed. Belay et al. [45] found a positive correlation of spore density with sand fraction under acacia species in central highlands of
Ethiopia. Sand fractions is known to have many macropores and this indicated the need of macropore spaces for increased AMF density. Spore density and root colonization were also positively related $[22,46]$. In contrast, a study by Alghamdi and Jais [47] in Saudi Arabia found a negative correlation of AMF with sand proportions but positive and strong correlation of AMF with silt and clay under Juniperus procera. This could be due to variation in the nature of the soil, climate, and the plant considered.

A positive correlation between AMF spore density and available phosphorus was observed. In line with this, Ong et al. [48] found positive correlation between spore count and soil available $\mathrm{P}$ due to the fact that the $\mathrm{P}$ concentration in the soil was low, thus allowing the enhancement of mycorrhizal sporulation. This finding is also in agreement with Muleta et al. [21] but in contrast to [22, 49] 
who found negative correlation between AMF and available phosphorus. This could be due to variation in root property of woody plants, climatic factors, and the phosphorus status of the plant.

\section{Conclusions}

The different soil and water conservation measures resulted in significant variation in AMF and soil nutrients. Slope position also brought relative variation in spore count and root colonization and need to be considered in the design of AMF and soil nutrient study of degraded landscapes. Exclosure management and supporting open grazing lands with terrace enhanced AMF spore density root colonization and soil nutrients. Therefore, community-based soil and water conservation practice is a dependable rehabilitation or restoration approach, which helps to boost the arbuscular mycorrhizal fungi and soil nutrients in degraded lands.

\section{Abbreviations}

Avail. P: available phosphorus; Avail. K: available potassium; OC: organic carbon; TN: total nitrogen; Ec: electrical conductivity; ARC: average root colonization.

\section{Authors' contributions}

MW was a Ph.D. student in soil science and participated in proposing the study, ran and managed all experiments, conducted all laboratory analyses, performed statistical analyses and interpretation of results, and drafted the manuscript. FK and BB as supervisors participated in reviewing the manuscript. EB was supervisor and participated in designing the field experiment and reviewed the manuscript in depth. All authors read and approved the final manuscript.

\section{Author details \\ ${ }^{1}$ College of Agriculture and Environmental Sciences, Haramaya University, P.O. Box 138, Dire Dawa, Ethiopia. ${ }^{2}$ Ethiopian Agricultural Transformation Agency, P.O. Box 708, Addis Ababa, Ethiopia. ${ }^{3}$ Department of Land Resources Manage- ment and Environmental Protection, Mekelle University, P.O. Box 231, Mekelle, Ethiopia. ${ }^{4}$ Faculty of Environmental Sciences and Natural Resource Manage- ment, Norwegian University of Life Sciences, P.O. Box 5003, 1432 Ås, Norway.}

\section{Acknowledgements}

We are grateful and appreciate Mekelle University forestry laboratory and Mekelle soil laboratory center for the technical and facility assistances.

\section{Competing interests}

The authors declare that they have no competing interests.

\section{Availability of data and materials}

Additional data may be available on request to the authors. Please contact corresponding author.

\section{Consent for publication}

The other authors in this study were supervisors to the corresponding author and provided their consent to the publication of this work.

\section{Ethics approval and consent to participate}

The authors declare that this study does not involve human subject's material and human data.

\section{Funding}

This study was funded by the ministry of education of Ethiopia.

\section{Publisher's Note}

Springer Nature remains neutral with regard to jurisdictional claims in published maps and institutional affiliations.

Received: 5 January 2018 Accepted: 11 April 2018

Published online: 25 April 2018

\section{References}

1. Yayneshet T, Eik LO, Moe SR. Seasonal variations in the chemical composition and dry matter degradability of exclosure forages in the semi-arid region of northern Ethiopia. Anim Feed Sci Technol. 2009;148:12-33.

2. World Food Program (WFP). Scaling up an integrated watershed management approach through social protection programs in Ethiopia: the MERET and PSNP schemes. In: Hunger, nutrition, climate, justice. Case studies: policy responses, local to national. Dublin, Ireland. 2013.

3. Mekuria W. Effectiveness of exclosures to restore ecosystem carbon stock and vegetation in the highlands of Tigray, northern Ethiopia. J Arid Environ. 2007;69:270-84.

4. Nyssen J, Munro N, Haile M, Poesen J, Descheemaeker K, Haregeweyn N, Decker J. Understanding the environmental changes in Tigray: a photographic record over 30 years. Tigray Livelihood Papers, No. 3. 2007. p. 82.

5. Nyssen J, Poesen J, Moeyersons J, Deckers J, Haile M, Lang A. Human impact on the environment in the Ethiopian and Eritrean highlands, a state of the art. Earth Sci Rev. 2004;64:273-320.

6. Descheemaeker K, Muys B, Nyssen J, Poesen J, Raes D, Haile M, Deckers J. Litter production and organic matter accumulation in exclosures of the Tigray highlands, Ethiopia. For Ecol Manag. 2006;233:21-35.

7. Gebrehiwot T, Veen AV. The effect of enclosures in rehabilitating degraded vegetation: a case of Enderta district, northern Ethiopia. Forest Res. 2014; ISBN 978-90-6164-297-8 ITC.

8. Birhane E, Kuyper TW, Sterck FJ, Bongers F. Arbuscular mycorrhizal associations in Boswellia papyrifera (frankincense-tree) dominated dry deciduous woodlands of northern Ethiopia. For Ecol Manag. 2010;260(12):2160-9.

9. Amare T, Terefe A, Selassie YG, Yitaferu B, Wolfgramm B, Hurni H. Soil properties and crop yields along the terraces and toposequece of Anjeni Watershed, central highlands of Ethiopia. J Agric Sci. 2013;5(2):134-44.

10. Amdemariam T, Selassie YG, Haile M, Yamoh C. Effect of soil and water conservation measures on selected soil physical and chemical properties and barley (Hordeum spp.) Yield. J Environ Sci Eng. 2011;5:1483-95.

11. Oehl F, Sieverding E, Ineichen K, Ma P, Boller T, Wiemken A. Impact of land use intensity on the species diversity of arbuscular mycorrhizal fungi in agroecosystems of central Europe. Appl Environ Microbiol. 2003;69(5):2816-24

12. Oruru MB, Njeru EM. Upscaling arbuscular mycorrhizal symbiosis and related agroecosystems services in smallholder farming systems. BioMed Res Int. 2016. https://doi.org/10.1155/2016/4376240.

13. Aminifar J, Sirousmehr A. Arbuscular mycorrhizal fungi community, nutrient availability and soil glomalin in organic farming. Int J Farming Allied Sci. 2014;3(1):1-6.

14. Li L, Li T, Zhang Y, Zhao Z. Molecular diversity of arbuscular mycorrhizal fungi and their distribution patterns related to host-plants and habitats in a hot and arid ecosystem, southwest China. Microbiology. 2010;71:418-27.

15. Brundrett M. Diversity and classification of mycorrhizal associations. Biol Rev. 2004;79:473-95.

16. Bedini S, Avio L, Argese E, Giovannetti M. Effects of long-term land use on arbuscular mycorrhizal fungi and glomalin-related soil protein. Agric Ecosyst Environ. 2007;120:463-6.

17. Rillig MC. Arbuscular mycorrhizae, glomalin, and soil aggregation. Can J Soil Sci. 2004;84:355-63.

18. Maciel C, Pereira R, Karla D, Carenna A, Ferreira DA, Tomio B, Costa L. Diversity of arbuscular mycorrhizal fungi in Atlantic forest areas under different land uses. Agric Ecosyst Environ. 2014;185:245-52.

19. Asmelash F, Bekele T, Birhane E. The potential role of arbuscular mycorrhizal fungi in the restoration of degraded lands. Front Microbiol. 2016;7:1-15. 
20. Barea JM, Palenzuela J, Cornejo P, Sanchez-Castro I, Navarro-Fernandez C, Lopez-Garcea AZC, Aguilar C. Ecological and functional roles of mycorrhizas in semi-arid ecosystems of Southeast Spain. J Arid Environ. 2011;75(12):1292-301.

21. Muleta D, Assefa F, Nemomissa S. Distribution of arbuscular mycorrhizal fungi spores in soils of smallholder agroforestry and monocultural coffee systems in southwestern Ethiopia. Biol Fertil Soils. 2008;44:653-9.

22. Birhane E, Aregawi K, Giday K. Changes in arbuscular mycorrhiza fungi spore density and root colonization of woody plants in response to exclosure age and slope position in the highlands of Tigray, northern Ethiopia. J Arid Environ. 2017. https://doi.org/10.1016/j.jaridenv.

23. Birhane E, Gebremedihin KM, Tadesse T, Hailemariam M, Solomon N Exclosures restored the density and root colonization of arbuscular mycorrhizal fungi in Tigray, northern Ethiopia. Ecol Process. 2017. https:// doi.org/10.1186/s13717-017-0101-9.

24. Beyth M. Paleozoic-mesozoic sedimentary basin of Mekele outlier. Am Assoc Petroleum Geol Bull. 1972;56:2426-39.

25. World reference base (WRB). A framework for international classification, correlation and communication. Rome: FAO; 2006.

26. Mekuria W, Aynekulu E. Exclosure land management for restoration of the soils in degraded communal grazing lands in northern Ethiopia. Land Degrad Dev. 2013;24:528-38.

27. Brundrett MC, Bougher N, Dell B, Grove T, Malajczuk N. Working with mycorrhizas in forestry and agriculture, vol. 32. Canberra: Australian Center for International Agricultural Research; 1996.

28. Schüßler A, Walker C. The Glomeromycota: a species list with new families and new genera. Gloucester: The Royal Botanic Garden Kew, Botanische Staatssammlung Munich, and Oregon State University; 2010.

29. McGonigle TP, Miller MH, Evans DG, Fairchild GL, Swan JA. A new method which gives an objective measure of colonization of roots by vesiculararbuscular mycorrhizal fungi. New Phytol. 1990;115:495-501.

30. Bouyoucos GJ. Hydrometer method improved for making particle size analyses of soil. Agron J. 1962;53:464-5.

31. Chopra SH, Kanwar JS. Analytical agricultural chemistry. New Delhi: Kalyani Publisher Ludhiana; 1976.

32. Walklay A, Black I. An examination of Degtjareff methods for determining soil organic matter and a proposed modification of the chromic acid titration method. Soil Sci. 1934;37:29-38.

33. Bremner JM, Mulvaney CS. Nitrogen, total methods of soil analysis. Part 2. Chemical and microbiological properties. Am Soc Agron. 1982;9:595-624.

34. Olsen SR, Sommers LE. Phosphorus. In: Page AL, et al., editors. Methods of soil analysis, Part 2. Chemical and microbiological properties. Madison: Soil Science Society of America; 1982.

35. Zangaro W, Rostirola LV, Eduardo L, Marques A. Root colonization and spore abundance of arbuscular mycorrhizal fungi in distinct successional stages from an Atlantic rainforest biome in southern Brazil. Mycorrhiza. 2013;23:221-33.
36. Lee EH, Eo JK, Ka KH, Eom AH. Diversity of arbuscular mycorrhizal fungi and their roles in ecosystems. Microbiology. 2013;41(3):121-5.

37. Wubet T, Kottke I, Teketay D, Oberwinkler F. Mycorrhizal status of indigenous trees in dry Afromontane forests of Ethiopia. For Ecol Manag. 2003;179:387-99.

38. Aggarwal A, Kadian N, Tanwar A, Yadav A, Gupta KK. Role of arbuscular mycorrhizal fungi (AMF) in global sustainable development. J Appl Nat Sci. 2011;3(2):340-51.

39. Borie F, Rubio R, Rouanet JL, Morales A, Borie G, Rojas C. Effects of tillage systems on soil characteristics, glomalin and mycorrhizal propagules in a Chilean Ultisol. Soil Tillage Res. 2006;88:253-61.

40. Jha DK. Diversity of arbuscular mycorrhizal fungi in undisturbed forest, slash-and-burn field, and monoculture forest of Indo-Burma megadiverse region. Braz J Bot. 2014;37:339-51.

41. Demelash M, Stahr K. Assessment of integrated soil and water conservation measures on key soil properties in South Gonder, North-Western Highlands of Ethiopia. J Soil Sci Environ Manag. 2010;1(7):164-76.

42. Murphy HF. A report on fertility status and other data on some soils of Ethiopia. Alemaya: Collage of Agriculture HSIU. Experimental Station Bulletin No. 44; 1968. p. 551.

43. FAO (Food and Agriculture Organization). Plant nutrition for food security a guide for integrated nutrient management. Rome: Fertilizer and Plant Nutrition Bulletin 16; 2006.

44. Buyinza M, Nabalegwa M. Effect of slope position and land-use changes to bio-physical soil properties in Nakasongola Pastoral Rangeland Areas, Central Uganda. Soil Erosion Issues in Agriculture; 2000.

45. Belay Z, Vestberg M, Assefa F. Diversity and abundance of arbuscular mycorrhizal fungi associated with acacia trees from different land use systems in Ethiopia. Afr J Microbiol Res. 2013;7(48):5503-15.

46. Chaudhry MS, Saeed M, Nasim FH. Soil chemical heterogeneity may affect the diversity of arbuscular-mycorrhizal fungi in the rhizosphere of Tamarix aphylla under arid climate. Biol Veget. 2013;59(2):53-63.

47. Alghamdi AM, Jais HM. Interaction between soil textural components, flavonoids in the roots and mycorrhizal colonization in Juniperus procera in Saudi Arabia. Afr J Microbiol Res. 2013;7(12):996-1001.

48. Ong KH, Chubo JK, King JH, Lee CS, Su DSA, Sipen P. Influence of soil chemical properties, on relative abundance of arbuscular mycorrhiza in forested soils in Malaysia. Turk J Agric For. 2012;36(4):451-8.

49. Dobo B, Asefa F, Asfaw Z. Mycorrhiazal association in relation to soil properties and plant species density in Sidama of Southern Ethiopia. Afr J Microbiol Res. 2016;10(29):1111-20.

\section{Submit your manuscript to a SpringerOpen ${ }^{\odot}$ journal and benefit from:}

- Convenient online submission

- Rigorous peer review

- Open access: articles freely available online

- High visibility within the field

- Retaining the copyright to your article

Submit your next manuscript at springeropen.com 